\title{
JOINT LESIONS OF HYPERPARATHYROIDISM
}

\author{
BY \\ E. G. L. BYWATERS, A. St. J. DIXON, AND J. T. SCOTT \\ From the Postgraduate Medical School of London and the M.R.C. Rheumatism Research Unit, \\ Taplow, Berks
}

While it is generally appreciated that synovitis and arthritis in their later stages involve bone, with erosion, pseudocyst formation, periostitis, and absorption of bone, leading in advanced cases to shortening of bone, the converse situation, that primary bone lesions may lead to joint disease, is not widely recognized. Patients with bone disease may present initially with articular symptoms and signs indistinguishable clinically from those seen in primary joint disease, and it is the object of this paper to present several fully studied examples of such "osteogenic" synovitis due to hyperparathyroidism. It will be shown that the common feature is softening and collapse of bone

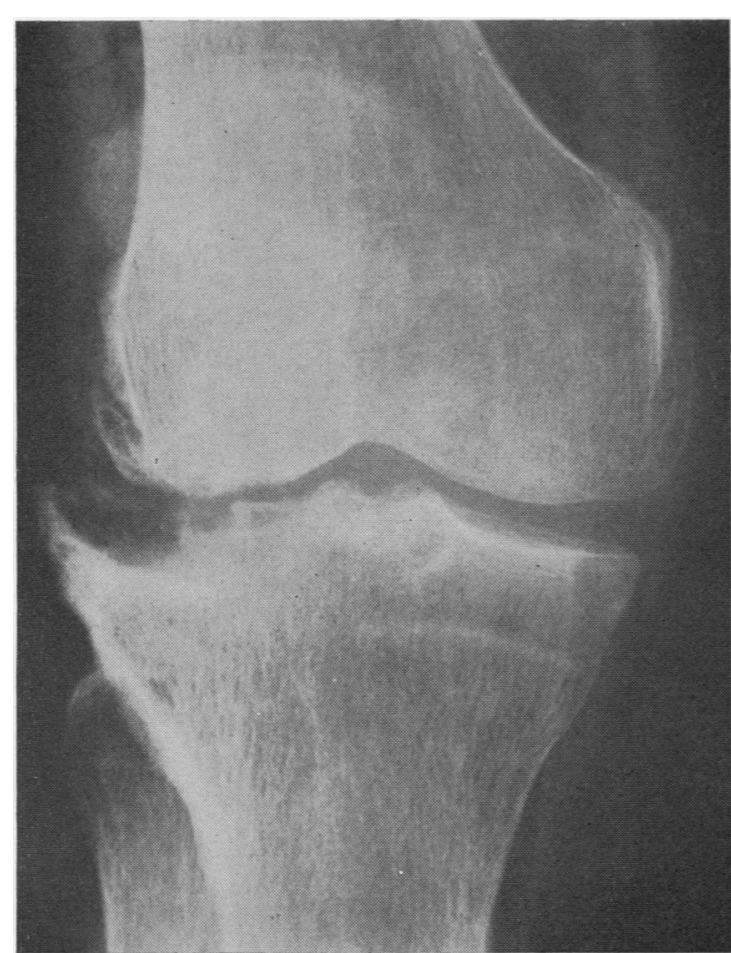

(a)

with the production of secondary "osteo-arthritis" (a preliminary account has already been published (Bywaters, 1959), and Zwaifler, Reefe, and Black (1962) have recently discussed this, describing three cases).

\section{Case Reports}

Case 1, a married woman born in 1891, was first seen elsewhere in 1953 with pain and swelling in both knees; this had been diagnosed as osteo-arthritis and treated with physiotherapy. The symptoms worsened progressively, so that when she was admitted on the Orthopaedic Service at Hammersmith Hospital for arthrodesis in 1957 (aged 66) she could scarcely walk at all and had not ventured out of the house for 2 years. She had some pain also in her back, hands, feet, and elbows; questioning

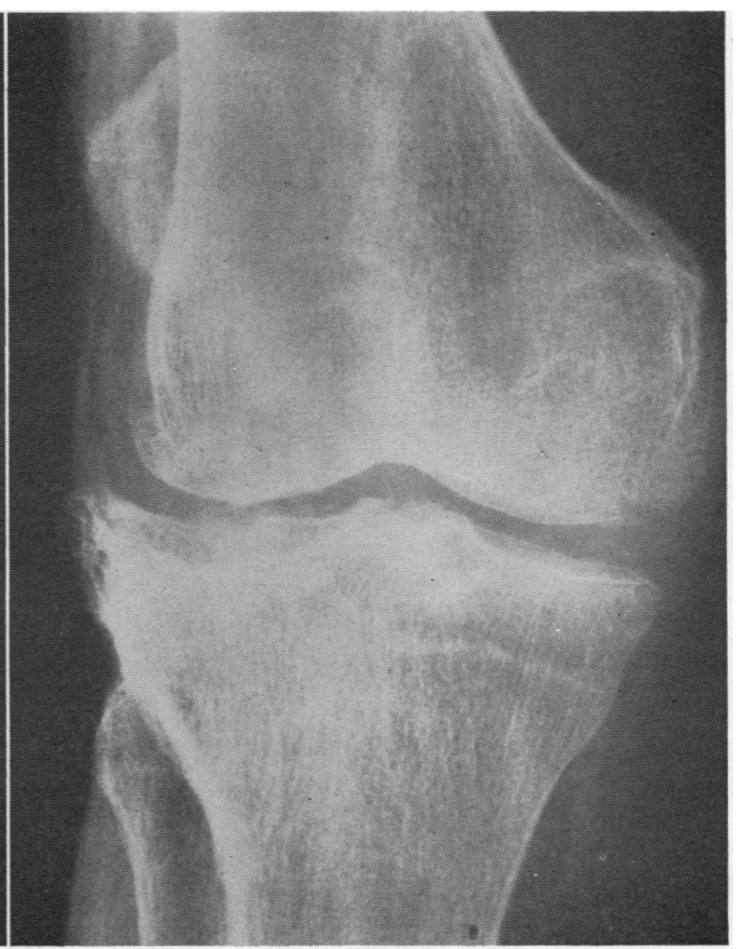

(b)

Fig. 1.-Case 1. Right knee (a) before and $(b) 1$ year after removal of parathyroid adenoma. Collapse and erosion of lateral condyle tibia and femur. 


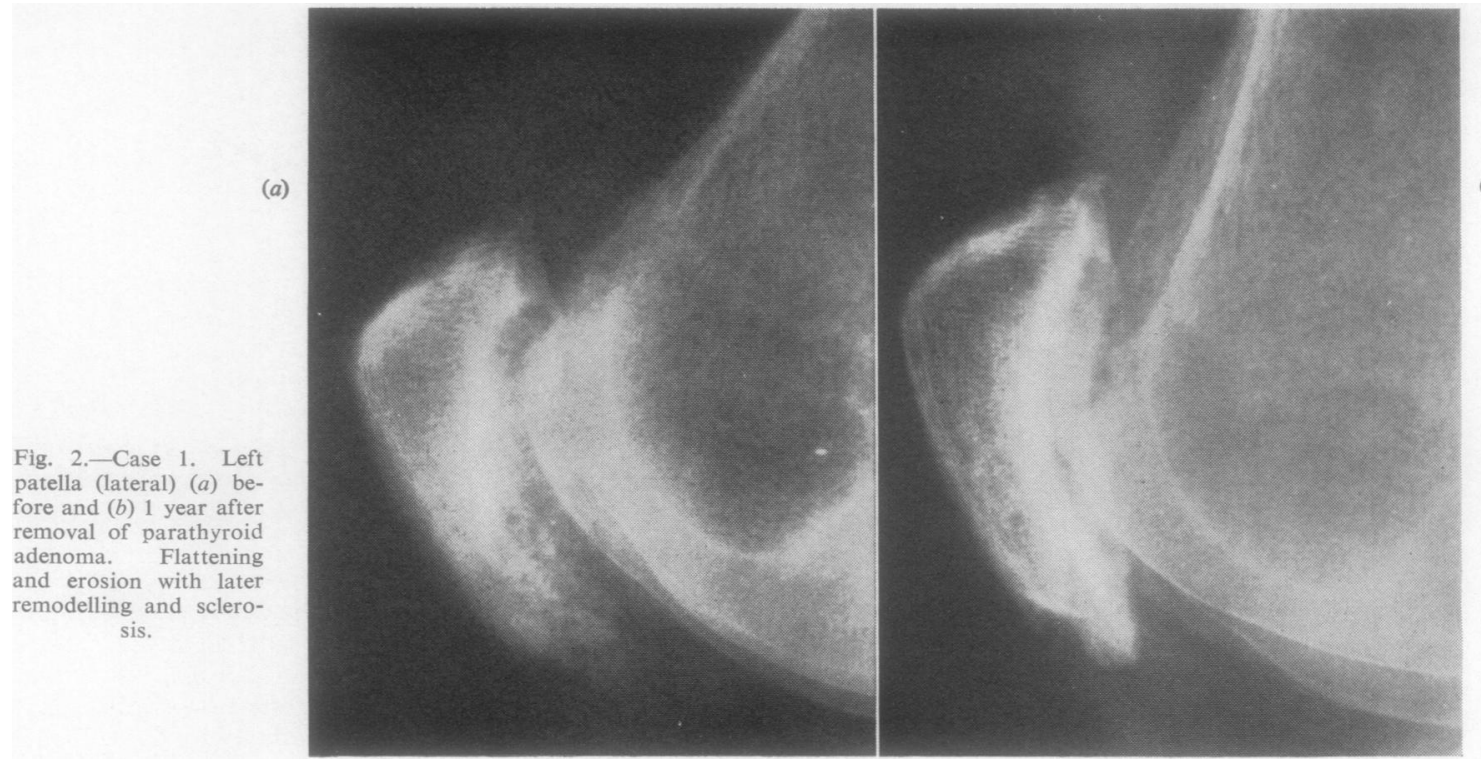

elicited that she had had some nausea with anorexia, constipation, thirst, and polyuria.

Examination.-There was considerable effusion in both knees, with crepitus, instability, and some valgus deformity (more marked on the right). There was also a $10^{\circ}$ limitation of full extension of the right elbow, some soft tissue swelling over the left wrist and the third left metatarsophalangeal joint, kyphosis, and a swelling in the front of the neck. She was thought perhaps to have rheumatoid arthritis, despite a negative Waaler-Rose test $(1: 8)$ and a normal erythrocyte sedimentation rate (3 and $8 \mathrm{~mm}$./hr Westergren), largely because $x$-ray examination of the knees showed gross erosions and collapse of the lateral tibial condyle (Fig. 1, see p. 171) and of the posterior part of the femoral condyle and patella (Fig. 2).

An $x$ ray of the hand, however, showed the classical subperiosteal resorption of hyperparathyroidism ("sawtooth edge") (Fig. 3), besides changes in the carpus closely resembling those of rheumatoid arthritis at the ulnar styloid and scapho-trapezoid joint (Fig. 4, opposite). The spine showed kyphosis caused by multiple areas of vertebral collapse.

Subsequent investigations revealed severe hyperparathyroidism with renal failure (serum Ca $6.3 \mathrm{mEq} / \mathrm{l}$.; $\mathrm{PO}_{4} 2.6 \mathrm{mEq} / \mathrm{l}$; alkaline phosphatase 105 KingArmstrong units; blood urea $85 \mathrm{mg}$. per cent.; serum $\mathrm{HCO}_{3} 16.9 \mathrm{mEq} / \mathrm{l}$.).

A strontium infusion test (Fraser, Harrison, and Ibbertson, 1960) showed a high bone calcium turnover, five times the normal value. Bone biopsy revealed osteitis fibrosa without abnormally wide osteoid seams.

Treatment.-A parathyroid adenoma was removed in 1958 with some temporary improvement, but after a stormy post-operative course progressive renal damage

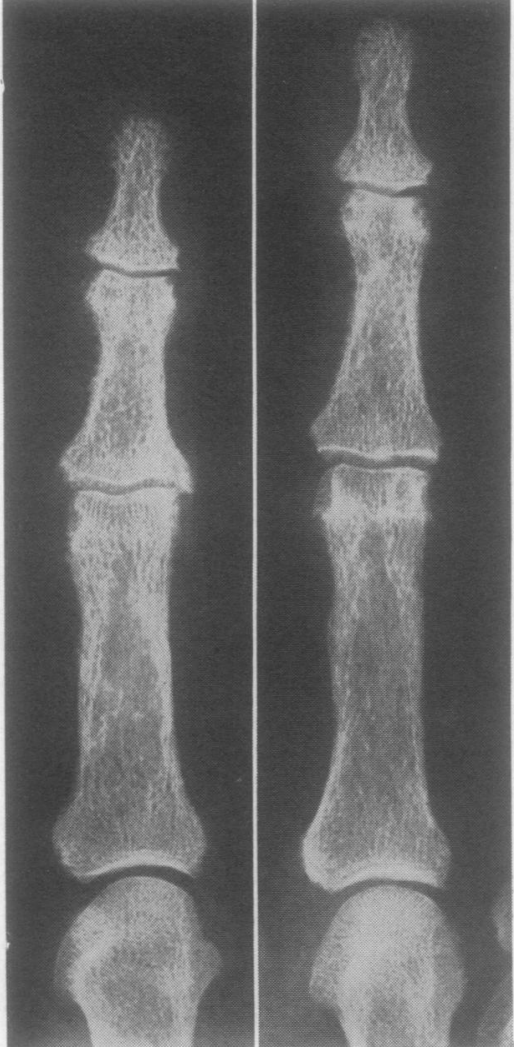

Fig. 3.-Case 1. Second and third fingers of right hand, showing sub-periosteal and subchondral bone absorption. 
(a)

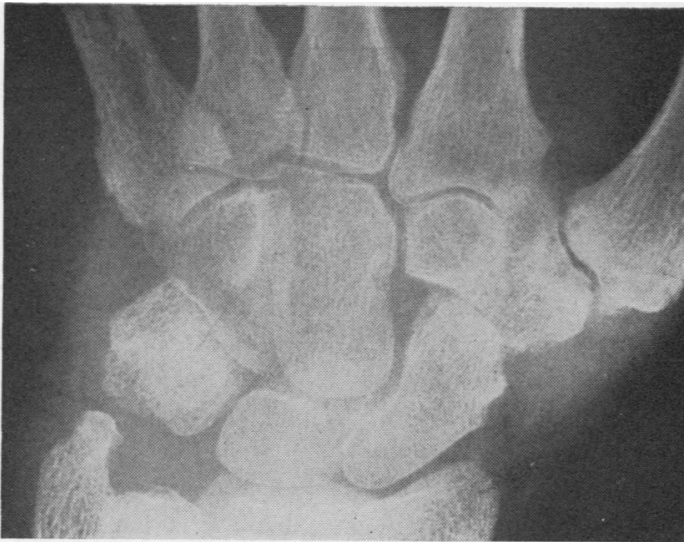

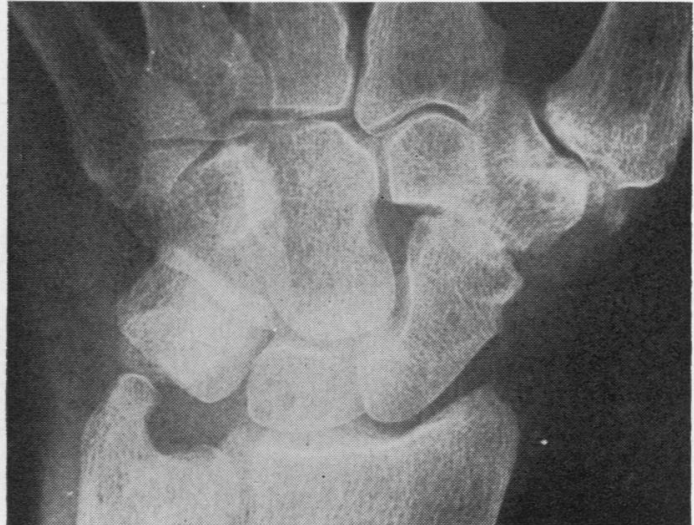

Fig. 4.-Case 1. Carpus, showing loss of cartilage and bone erosion in ulnar styloid and scapho-trapezoid joint (a) before and (b) 1 year after removal of adenoma. lead to the patient's death 16 months later, before which secondary osteomalacia with wide osteoid seams was shown in a further iliac crest biopsy.

Autopsy.-This revealed polycystic kidneys (combined weight 312 g.). No parathyroid tissue was found. The knee lesion was due to collapse of bone with secondary osteo-arthritis change and fibrocartilage repair
(Fig. 5). Fragments of necrotic trabeculae and haemosiderin-containing macrophages were found deep in the substance of the bone, the surface of the affected tibial condyle being roughened and covered with fibrocartilage. Osteitis fibrosa was not found but osteomalacia was present. The synovial membrane showed a mild synovitis only, with haemosiderin-containing macrophages and fragments of necrotic bone embedded

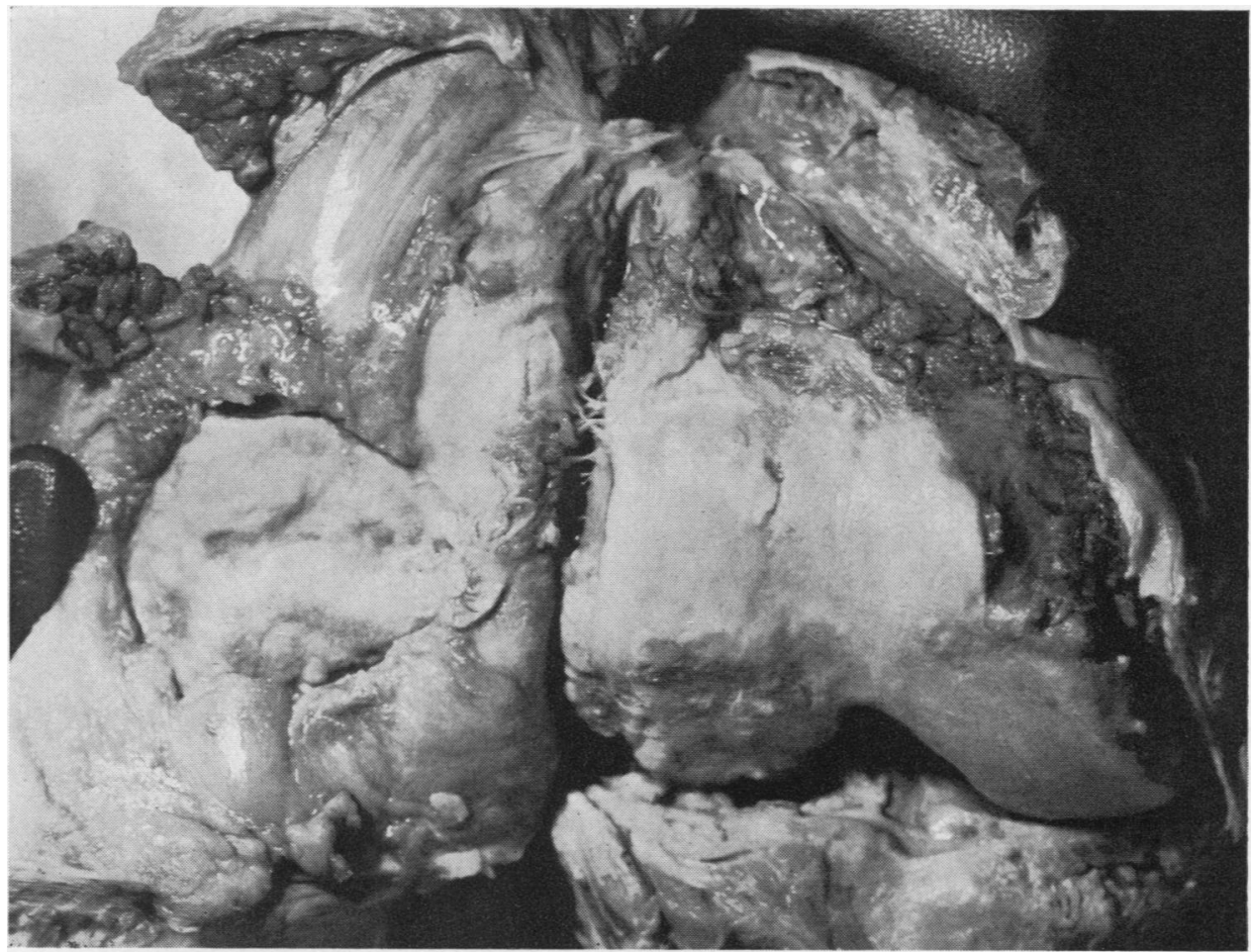

Fig. 5.-Case 1. Right knee (post mortem), showing preservation of medial and collapse of lateral femoral and tibial condyles. 


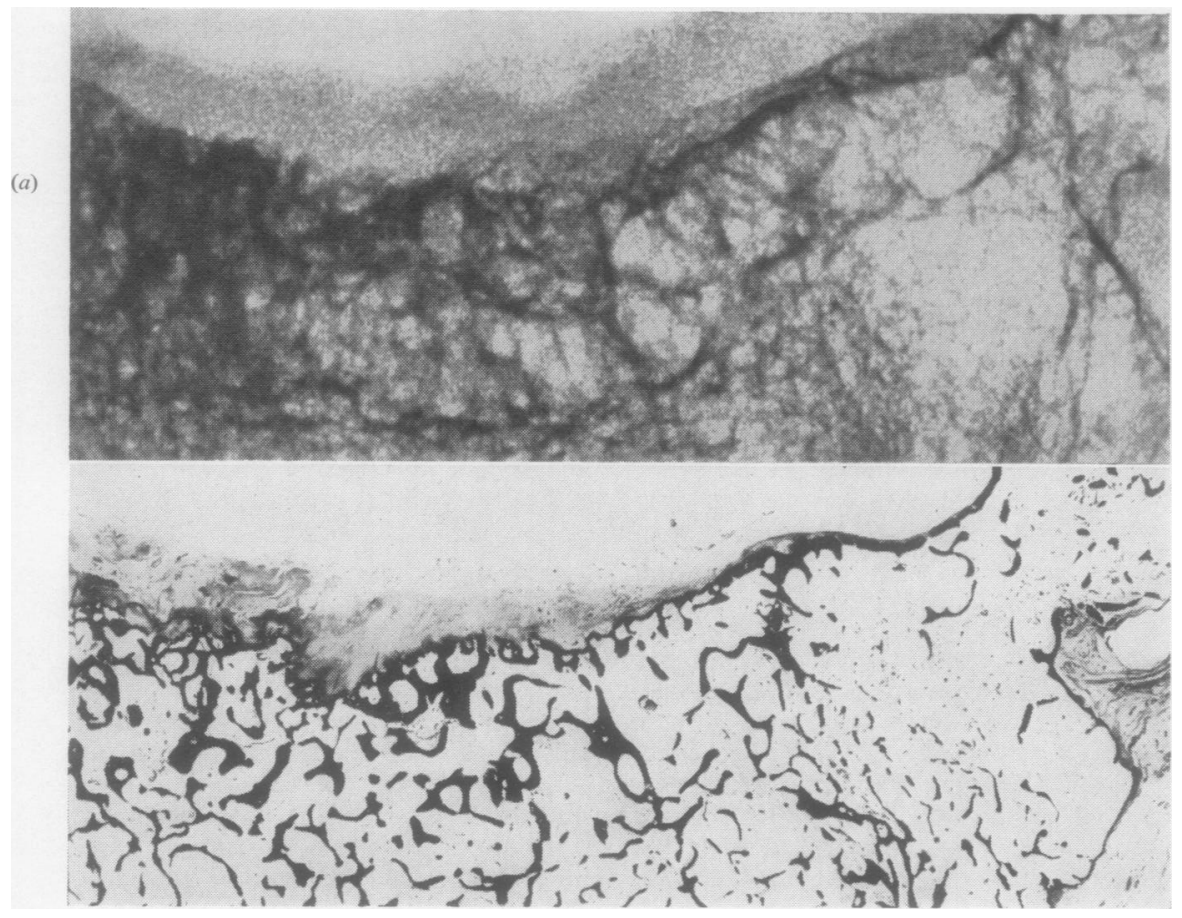

Fig. 6.-Case 1. Right knee. showing outer part of $(a)$ lateral and $(b)$ medial condyle of tibia (coronal slice). $X$ ray (above) and photomicrograph (below). $\times 4.5$.

Note collapse of bone trabeculae and of cartilage with secondary osteo-arthritic change and osteophytes in $(a)$ and normal appearance in $(b)$.

in it. The $x$-ray and histological appearance of contiguous slices from the normal and abnormal tibial plateaux (Fig. $6 a, b$ ) and femoral condyles (Fig. $7 a, b$, opposite) show that the lesion is essentially due to localized subchondral trabecular fractures. Similar areas of healed erosion or collapse were seen in the interphalangeal joints. There was no sign of inflammatory synovitis.

Comment.-This case mimicked clinically and radiologically the appearances of rheumatoid arthritis, where erosions occur at the same sites. The lateral view of the patellae, however, was unique; it appeared to be wrapped round the femur (Fig. 2), and this characteristic enabled us to recognize the second case at an earlier stage.
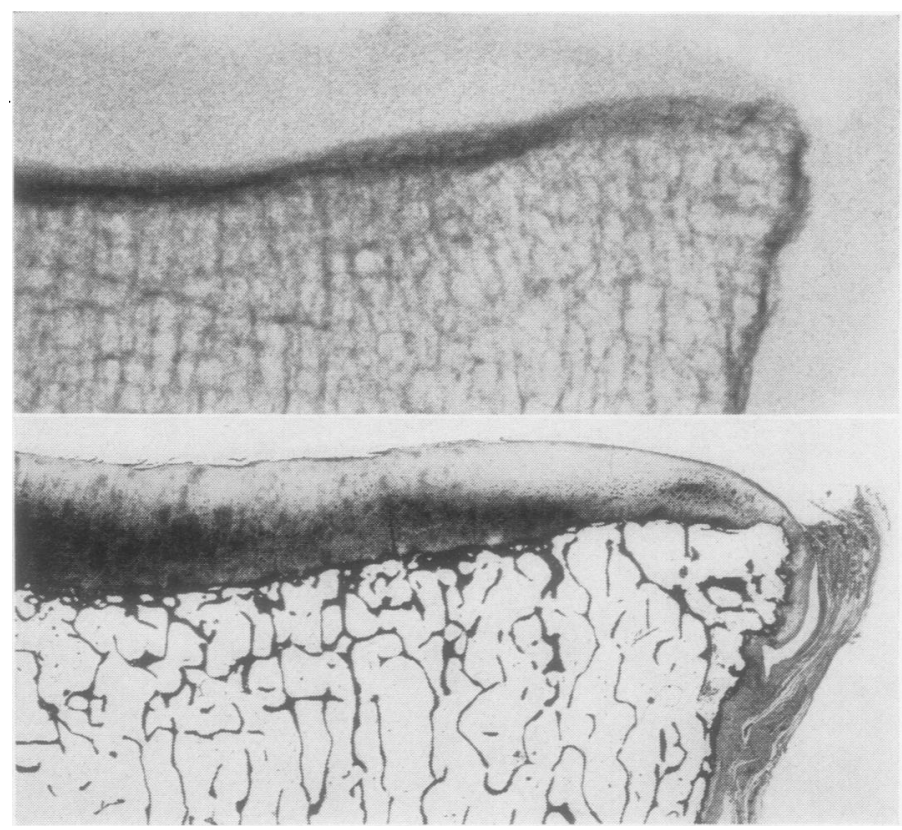
(a)

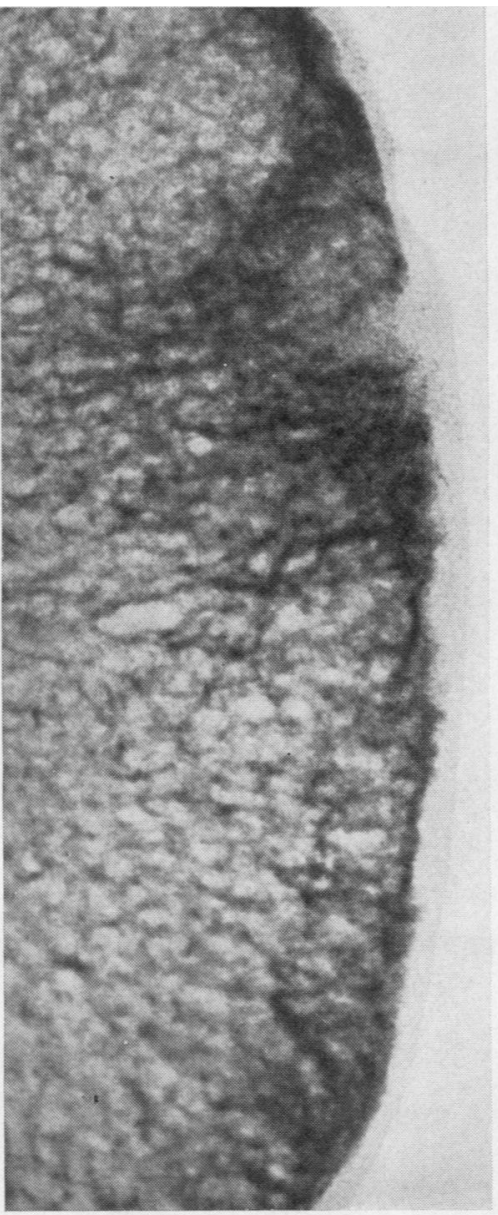

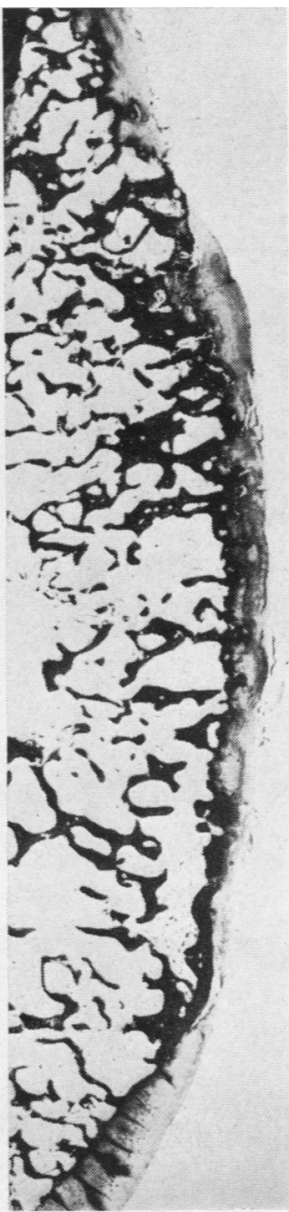

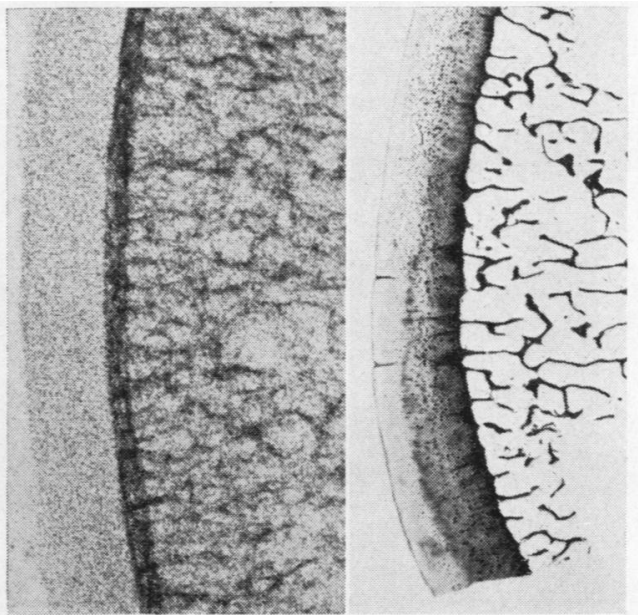

Fig. 7.-Case 1. Right knee, showing lower part of (a) lateral and $(b)$ medial femoral condyle (sagittal slice). $X$ ray (left) and photomicrograph (right). $\times 4 \cdot 5$.

Note pathological changes in $(a)$ and normal appearance in $(b)$.
Case 2, a woman born in 1900 , was admitted in 1958 with weakness of the legs and swelling of the knees ("like balloons") for 3 years, difficulty in walking, and backache. The right knee in particular had been recently swollen. She had also had some recent loss of weight (28 lb.) with fatigue, vomiting, and polyuria. She had had duodenal ulcer symptoms in 1940.

Examination.-There was some $10^{\circ}$ lack of full extension in the right knee, with thickening of synovial membrane in both knees, and transverse striae distensae in the skin over the quadriceps pouches. The erythrocyte sedimentation rate was $7 \mathrm{~mm}$./ hr (Westergren). The Waaler-Rose test was negative.

An $x$ ray of the skull showed characteristic signs of hyperparathyroidism with an osteolytic lesion of the frontal bone. Both knees showed calcification in the suprapatellar pouch and deformed patellae "wrapped round" the femora (Fig. 8, overleaf). There were no erosions of the tibial or femoral surfaces. $X$ rays of the hands showed characteristic signs of hyperpara- thyroidism in the phalanges and superficial erosions of both ulnar styloids (Fig. 9, overleaf), like those found in rheumatoid arthritis, and marginal erosions of the metacarpal heads producing a hook-like deformity, also as in rheumatoid arthritis (Fig. 10, overleaf). $X$ rays of the pelvis showed apparent erosions of the lower end of the right sacro-iliac joint and of the symphysis pubis, erosions of the ischial rami and the lesser trochanter, and a curious coxa vara deformity of both femoral necks (also seen in Case 11) (Fig. 11, overleaf).

Biochemical studies confirmed hyperparathyroidism (Ca $7.8 \mathrm{mEq} / \mathrm{l}$; phosphorus $1.9 \mathrm{mEq} / \mathrm{l}$; alkaline phosphatase 135 King-Armstrong units; blood urea 55 mg. per cent.). A bone biopsy showed osteitis fibrosa and osteoid seams of maximal normal width.

Treatment and Progress.-A parathyroid adenoma was removed. One year later there was considerable re-calcification but osteolytic areas persisted in the skull and in the mid-femoral shaft. The erosive lesions in the ulnar styloids and the metacarpophalangeal joints had undergone some healing, but there was permanent residual loss of subchondral bone from each of these sites (Figs 9 and 10). The synovial calcification was less, but 2 years after the operation (September, 1961) the patient still had an occasional episode of pain in the left knee. 


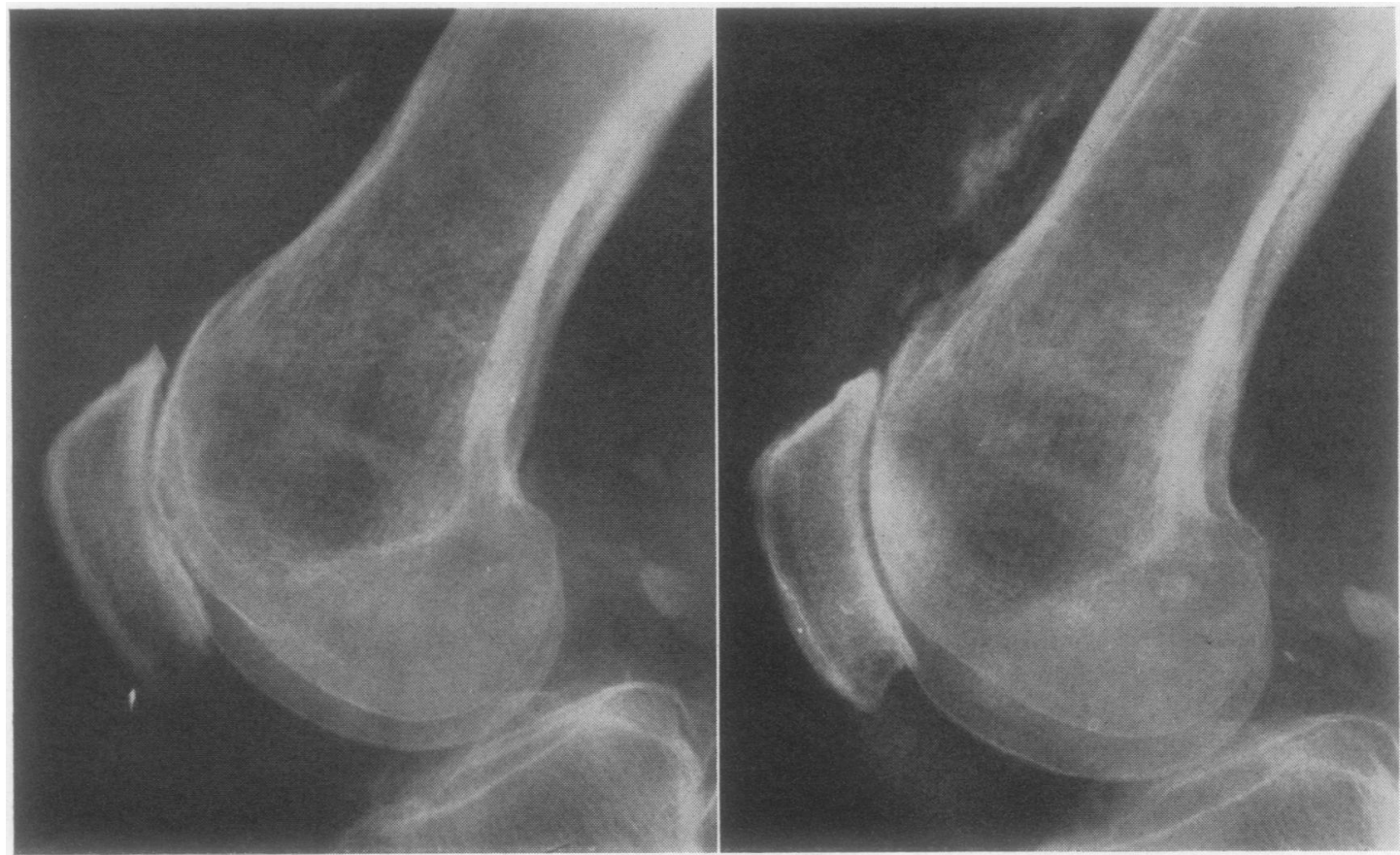

Fig. 8.-Case 2. Lateral radiographs of left and right knees.

(a)

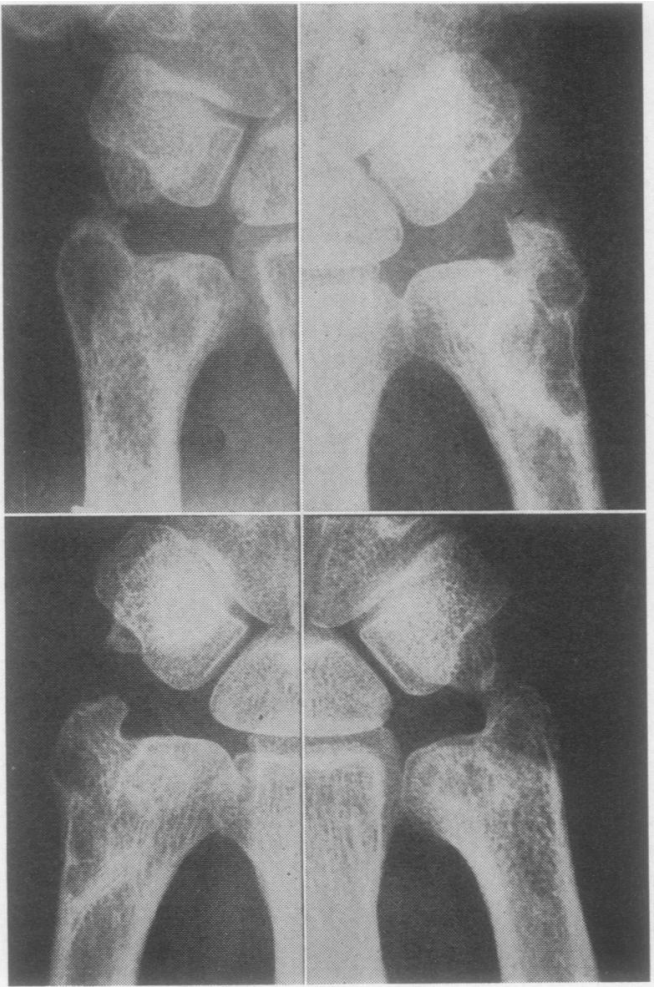

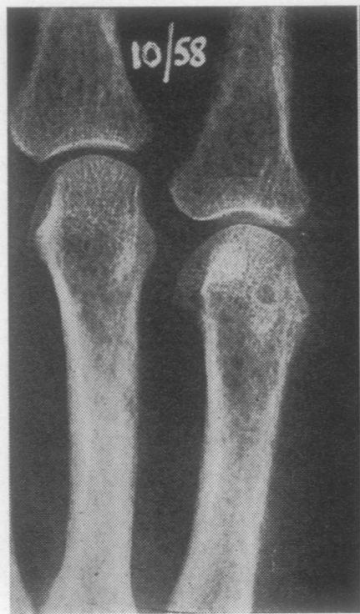

(a)

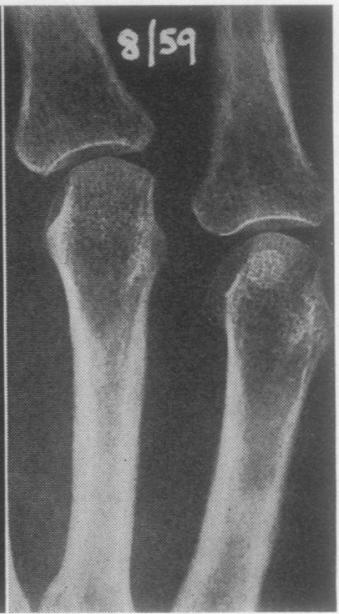

(b)

Fig. 10.-Case 2. Metacarpal heads (a) before and (b) 10 months after removal of parathyroid adenoma. Note subchondral bone erosion producing "hook".

Fig. 9.-Case 2. Erosions of ulnar styloids $(a)$ before and $(b) 1$ year after removal of parathyroid adenoma. 


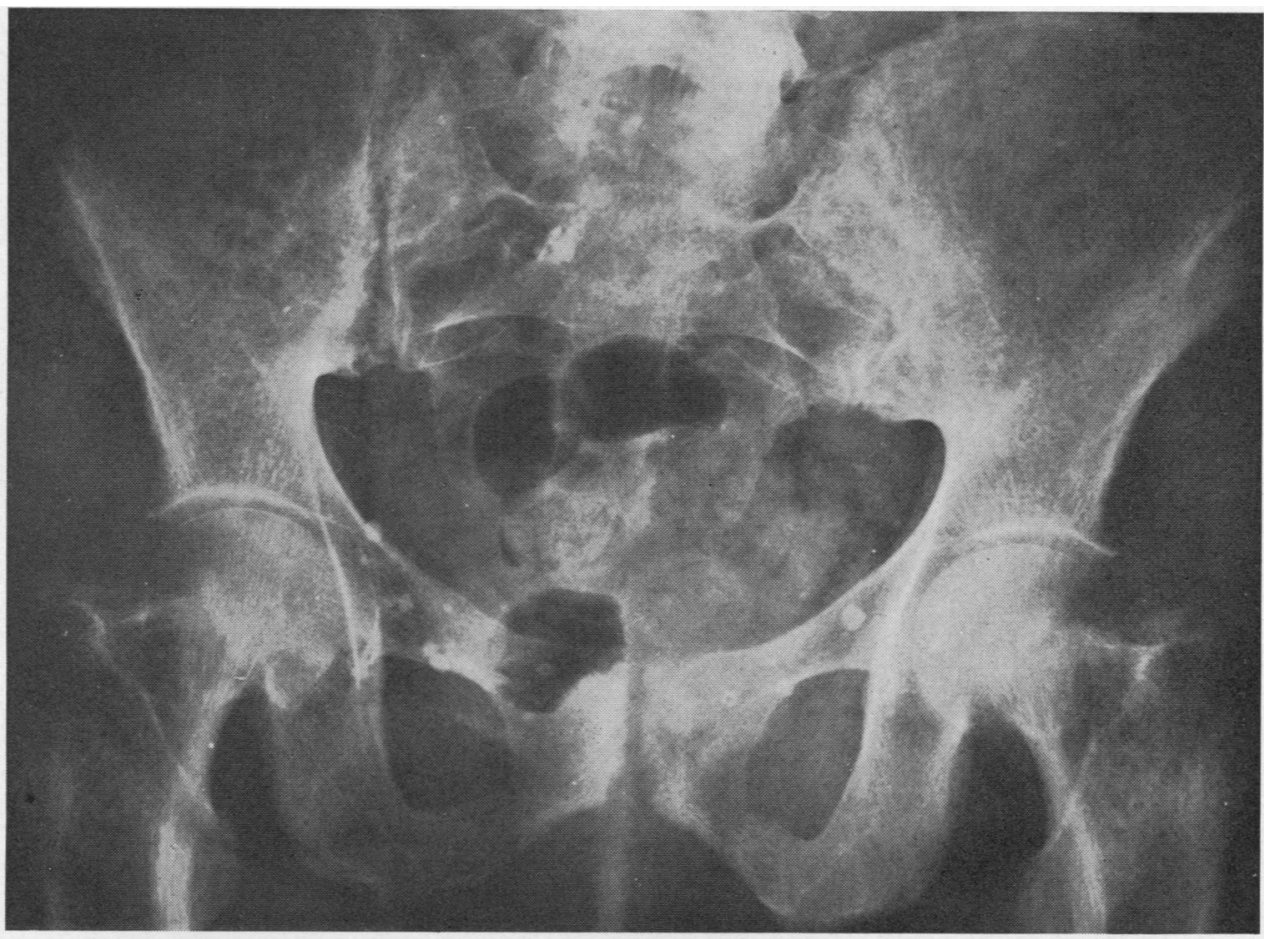

Fig. 11.-Case 2. Pelvis, showing coxa vara and erosion of pelvic bones.

Case 3, a woman born in 1887, was admitted in November, 1959, complaining of severe pain and swelling in both knees for 4 months, which rendered her quite unable to walk. This had been treated elsewhere with phenyl-butazone without benefit.

Examination.-The right knee was hot, swollen, and tender. There was also swelling in the right side of the neck. The urine showed a low specific gravity $(1,012)$ and proteinuria. The erythrocyte sedimentation rate was $8 \mathrm{~mm}$./hr; blood urea $72 \mathrm{mg}$. per cent.; calcium 9.6 mEq/1.; phosphorus $2.2 \mathrm{mEq} / \mathrm{l}$.; alkaline phosphatase 21 King-Armstrong units.

$X$ rays showed a "rugger-jersey" spine, and changes characteristic of hyperparathyroidism in the subperiosteal bone of the fingers. The knees showed calcification of the menisci and in the suprapatellar pouch. The patella showed some posterior erosion where it lay in contact with the femur (Fig. 12). There was also a line of calcification in the posterior capsule.

A needle biopsy of the synovial membrane (Dr. John Glyn) showed mild synovitis without round cell or plasma cell infiltration compatible with a diagnosis of degenerative joint disease but without calcification.

Treatment.-A parathyroid adenoma was removed, and there was some improvement when she was last seen one month later.

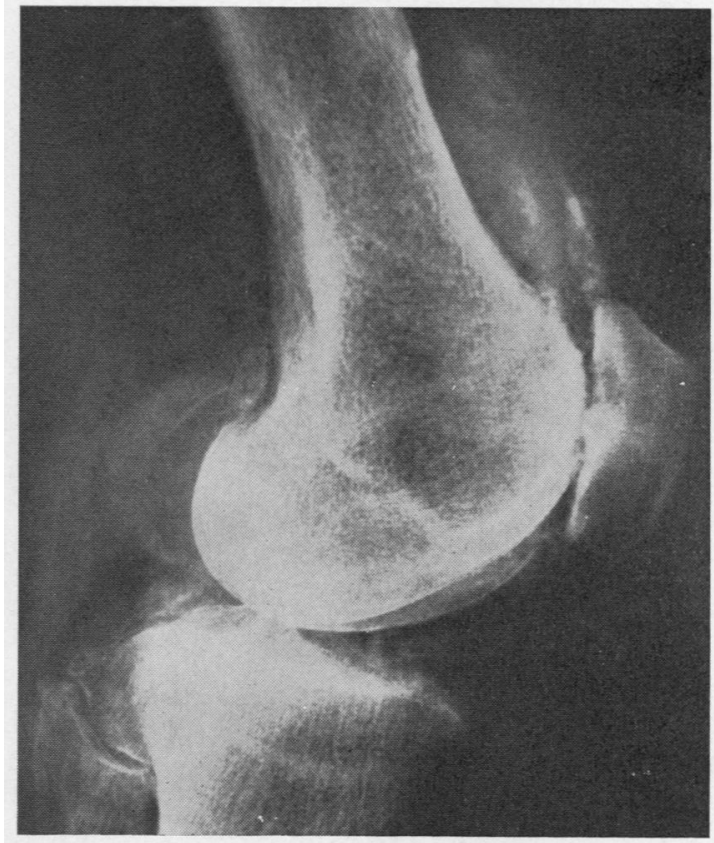

Fig. 12.-Case 3. Lateral radiograph of right knee, showing calcification and erosions. 
Case 4, a man born in 1891, was admitted to the West London Hospital in December, 1961, with a 5-week history of pain in the thoracic region of the back. He had himself noticed increasing curvature of the spine for several months with a loss of 4 inches in height. For 4 years he had complained of intermittent epigastric pain after meals. There had been a single episode of renal colic in 1919.

Examination.- He was of small physique with generalized skin pigmentation, a patch of buccal pigmentation, marked thoracic kyphosis, and a small deposit of calcium in the right cornea. The right elbow and both knees lacked full extension by a few degrees, but the joints were otherwise normal. The blood pressure 140/90; erythrocyte sedimentation rate $10 \mathrm{~mm} . / \mathrm{hr} ; \mathrm{Hb} .85$ per cent.; white blood count 6,200 ; serum calcium $7 \cdot 1$ $\mathrm{mEq} / \mathrm{l}$.; serum phosphorus $1.7 \mathrm{mEq} / \mathrm{l}$; alkaline phosphatase 78 King-Armstrong units; serum albumin 2.8 g. per cent.; globulin 1.7 g. per cent.; blood urea $84 \mathrm{mg}$. per cent. Urine protein $0.38 \mathrm{~g}$. in $24 \mathrm{hrs}$; maximum urine concentration 1,010 .

$X$ rays of the hands and feet showed subperiosteal erosions typical of hyperparathyroidism and soft tissue calcification was seen in the neighbourhood of various
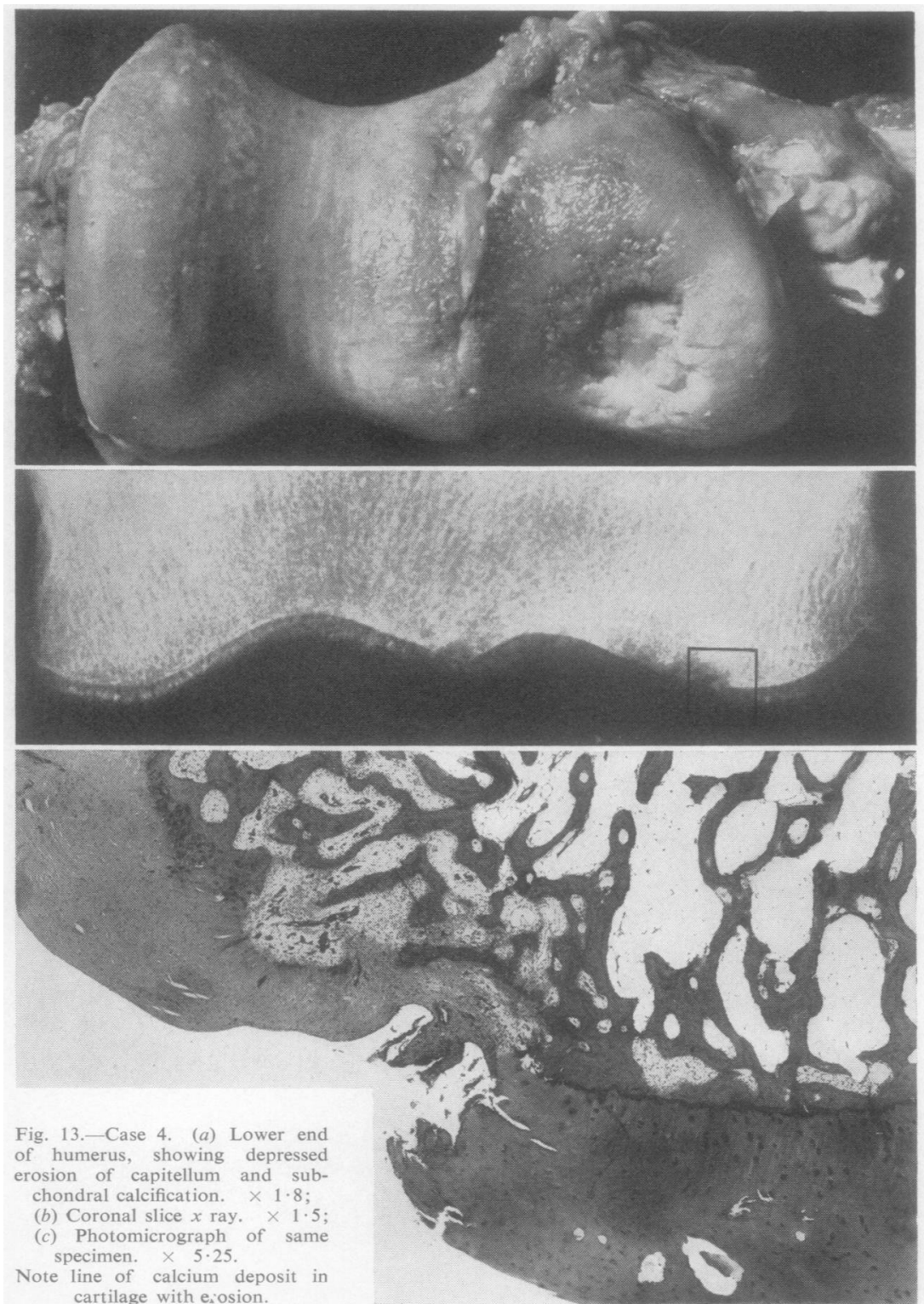
joints. $X$ rays of the vertebrae showed a "ruggerjersey" appearance with collapse of several vertebral bodies and gross subluxation of $\mathrm{C5}$ on $\mathrm{C6}$. $X$ ray of the pelvis showed a single Looser's zone.

Intravenous pyelogram showed poor dye concentration in small contracted kidneys with calcification in the right kidney. Barium meal showed a small lesser curve ulcer.

Treatment.-After ACTH stimulation there was a normal rise in the urinary 17-hydroxycorticosteroids. A parathyroid adenoma was removed in January, 1962, and after the operation the patient became hypotensive and oliguric, the blood urea rising rapidly to $485 \mathrm{mg}$. per cent. He was transferred to Hammersmith Hospitai for dialysis, but died within a few hours of transfer.

Autopsy.-There was mucopurulent bronchitis and patchy bronchopneumonia. Kidneys showed the changes of chronic glomerulonephritis. Metastatic calcification was found in the vicinity of many joints: Fig. 13 shows calcification and erosion in the articular cartilage at the lower end of the humerus with subchondral bone collapse.

Fig. 14 shows compression and disruption of porotic cervical vertebrae by ballooning intervertetral disks in which foci of calcification can be seen.

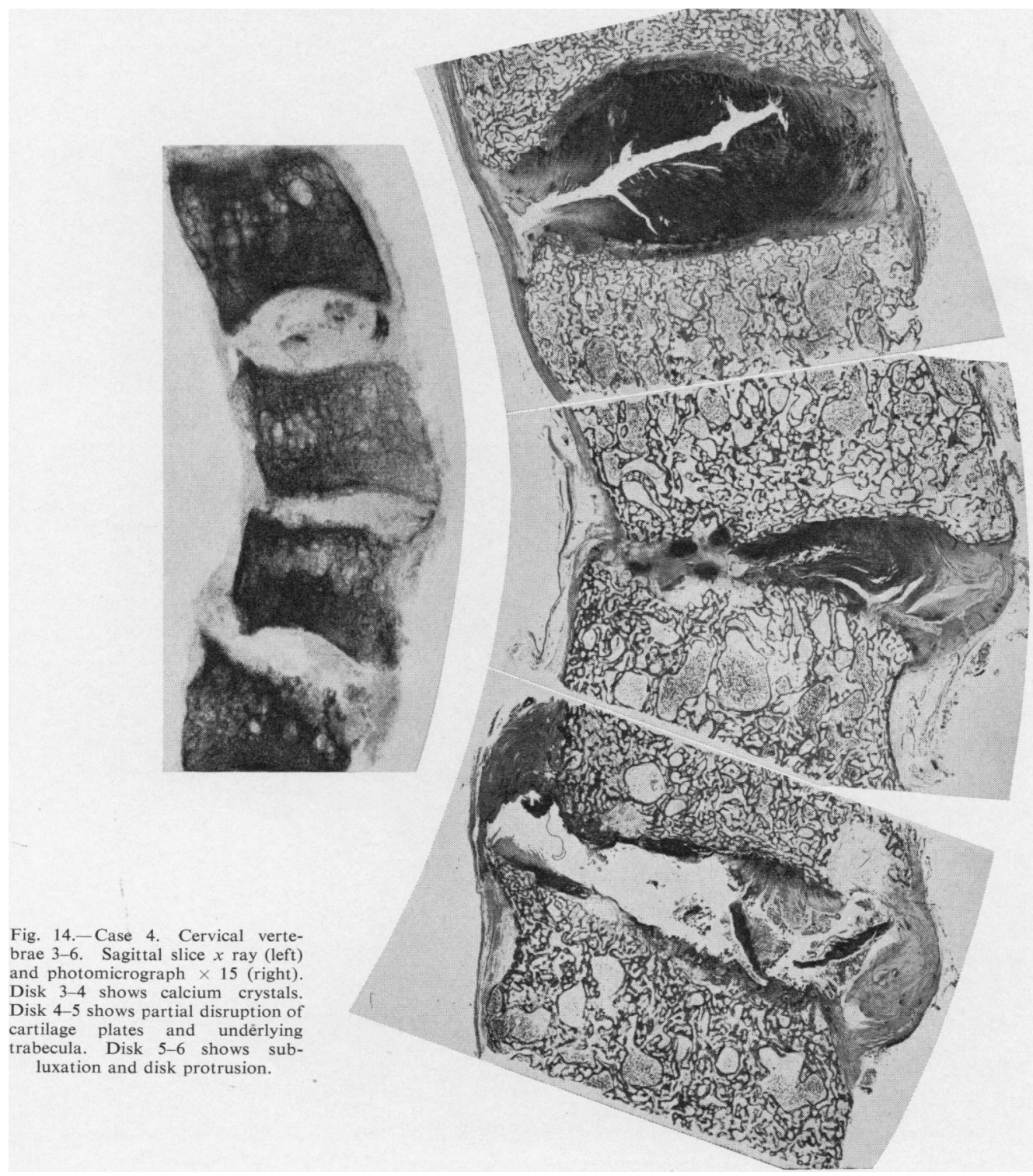


The knees showed calcification in the articular and there was also calcification in tendon sheaths (Fig. 18, cartilage, menisci, and synovium (Figs 15, 16, 17) opposite).

Fig. 15.-Case 4. $X$ ray of knee, showing calcification of cartilage, menisci, and soft tissues.

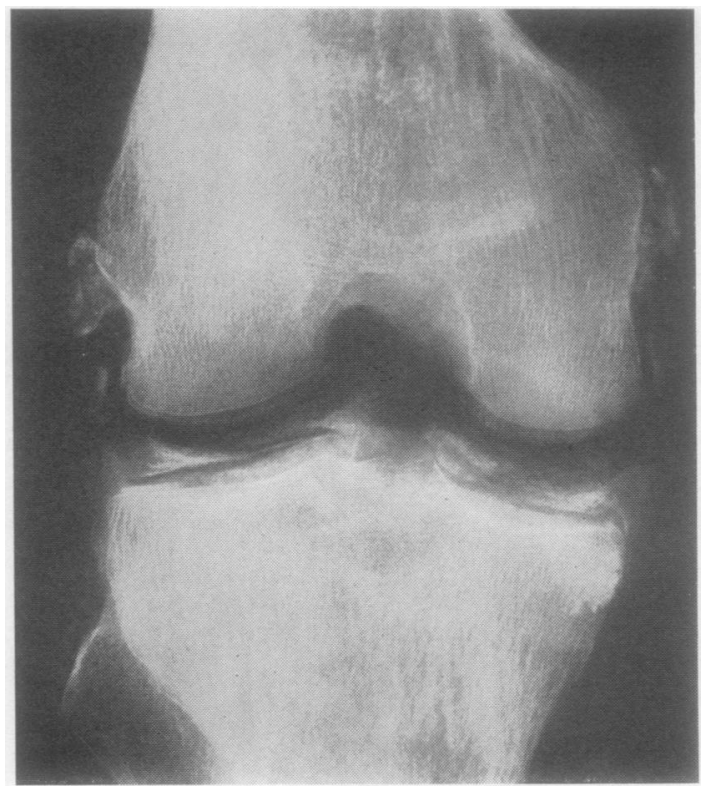

9. 16. - Case 4. Knee at autopsy, showing calcification in cartilage, menisci, and synovium.
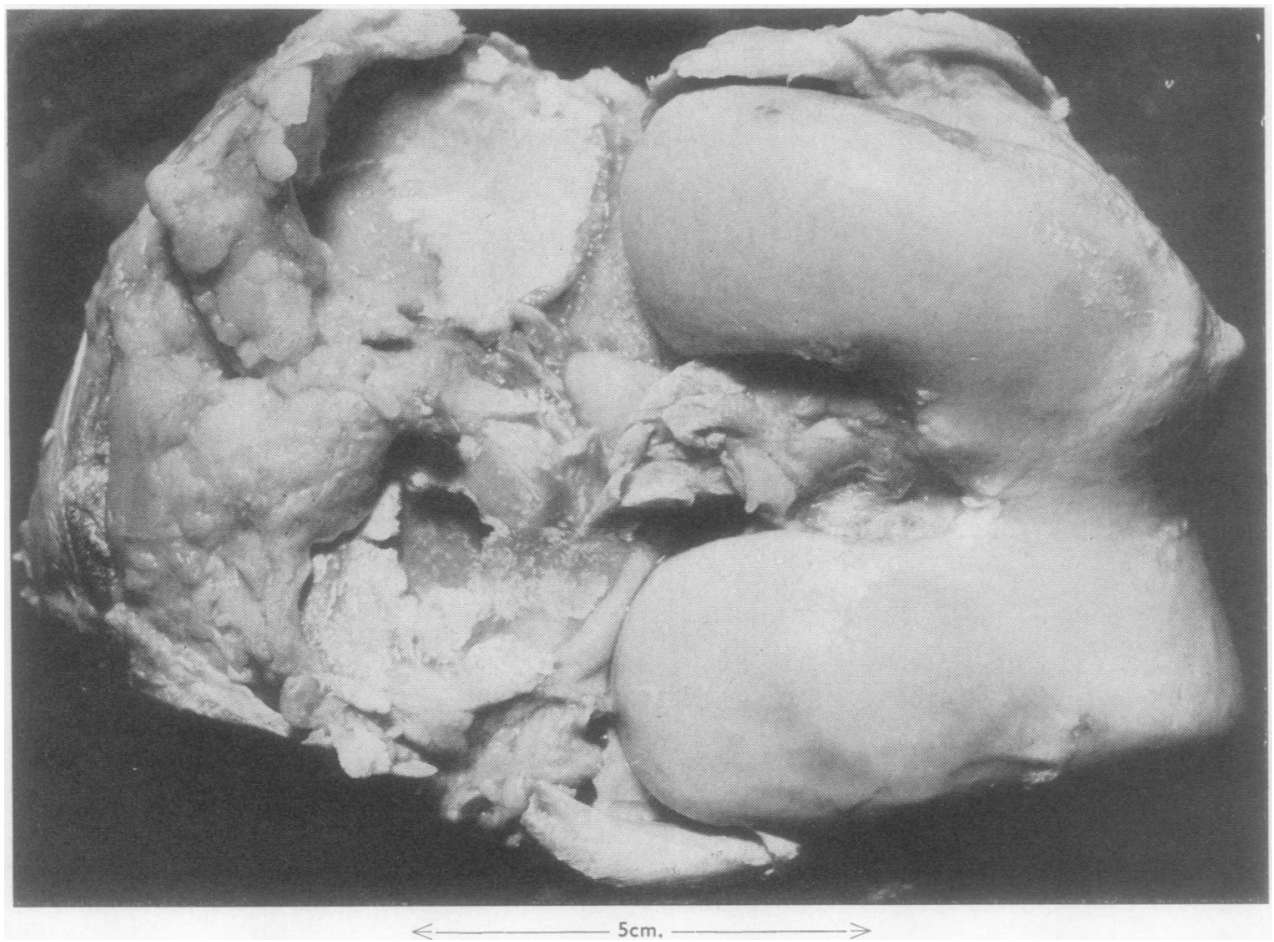


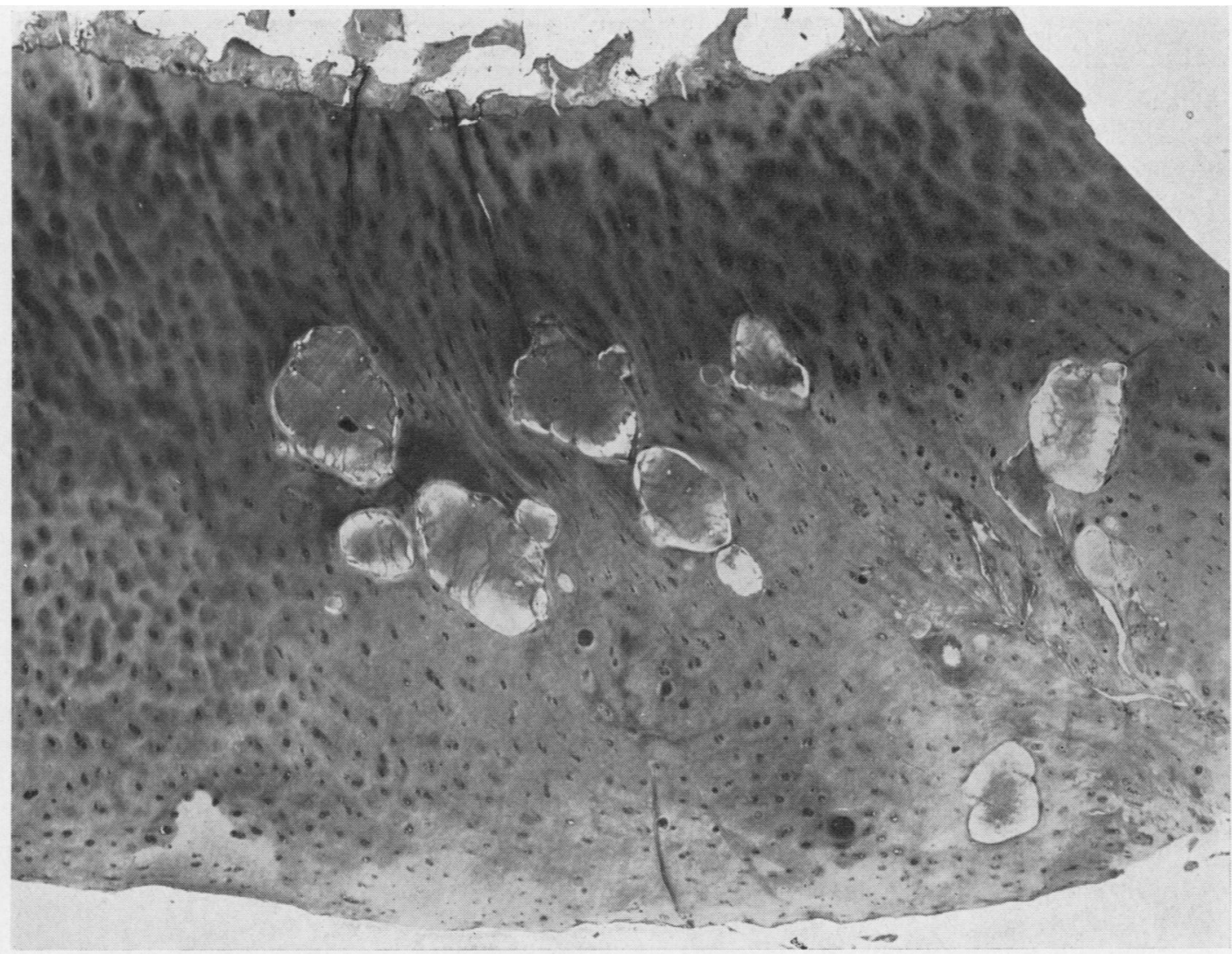

Fig 17.-Case 4 Photomicrograph of medial femoral condyle, showing foci of calcification within articular cartilage (mid-zonal) Decalcified, haematoxylin and eosin. $\times 30$.

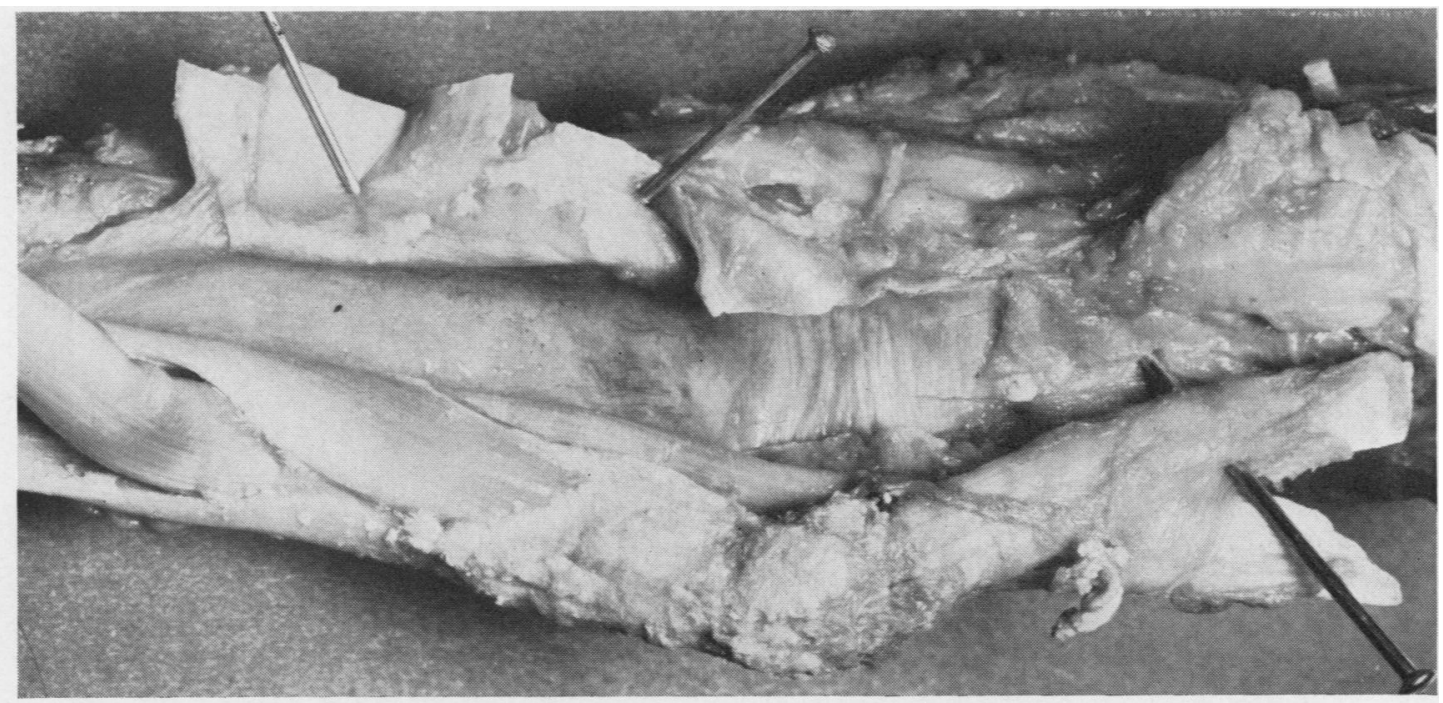

Fig. 18.-Case 4. Palmar flexor tendon sheath at autopsy, showing superficial calcification (not on deep surface). 
TABLE

\begin{tabular}{|c|c|c|c|c|c|c|c|c|}
\hline $\begin{array}{l}\text { Case } \\
\text { No. }\end{array}$ & Sex & $\begin{array}{c}\text { Age at } \\
\text { Admission } \\
\text { (yrs) }\end{array}$ & $\begin{array}{c}\text { Blood Urea } \\
\text { before } \\
\text { Operation } \\
\text { (mg. per cent.) }\end{array}$ & $\begin{array}{c}\text { Alkaline } \\
\text { Phosphatase } \\
\text { (King-Armstrong } \\
\text { Units) }\end{array}$ & $\begin{array}{c}\text { Erythrocyte } \\
\text { Sedimentation } \\
\text { Rate } \\
(\mathrm{mm} . / \mathrm{hr})\end{array}$ & $\begin{array}{l}\text { Joint Pain (P) } \\
\text { Effusion (E) }\end{array}$ & $\begin{array}{l}\text { Calcification } \\
\text { in Soft } \\
\text { Tissues }\end{array}$ & $\begin{array}{l}\text { Erosions seen } \\
\text { Radiologically }\end{array}$ \\
\hline $\begin{array}{r}1 \\
2 \\
3 \\
4 \\
5 \\
6 \\
7 \\
8 \\
9 \\
10 \\
11 \\
12 \\
13 \\
14 \\
15 \\
16 \\
17 \\
18 \\
19\end{array}$ & $\begin{array}{l}F \\
F \\
F \\
M \\
F \\
F \\
F \\
F \\
M \\
F \\
F \\
F \\
F \\
F \\
F \\
F \\
M \\
F \\
F\end{array}$ & $\begin{array}{l}66 \\
58 \\
72 \\
70 \\
69 \\
74 \\
66 \\
61 \\
41 \\
73 \\
66 \\
55 \\
40 \\
57 \\
57 \\
26 \\
33 \\
74 \\
32\end{array}$ & $\begin{array}{r}70 \\
55 \\
72 \\
84 \\
58 \\
35 \\
57 \\
70 \\
170 \\
173 \\
66 \\
38 \\
55 \\
17 \\
32 \\
27 \\
70 \\
76 \\
41\end{array}$ & $\begin{array}{r}105 \\
135 \\
21 \\
78 \\
41 \\
28 \\
34 \\
74 \\
32 \\
22 \\
100 \\
78 \\
9 \\
37 \\
32 \\
11 \\
10 \\
18 \\
42\end{array}$ & $\begin{array}{r}8 \\
7 \\
8 \\
- \\
- \\
9 \\
120 \\
18 \\
57 \\
29 \\
37 \\
9 \\
15 \\
7 \\
7 \\
1 \\
36 \\
13\end{array}$ & $\begin{array}{l}\text { PE } \\
P E \\
P E \\
P \\
P E \\
P E \\
P E \\
P^{*} \\
0^{*} \\
P \\
P E \\
P \\
0^{*} \\
0 \\
0 \\
0^{*} \\
0^{*} \\
P E \\
0\end{array}$ & \begin{tabular}{c}
0 \\
+ \\
+ \\
+ \\
$\ddot{0}$ \\
0 \\
+ \\
\hdashline \\
0 \\
+ \\
0 \\
+ \\
0 \\
0 \\
+ \\
0 \\
0 \\
-- \\
-
\end{tabular} & 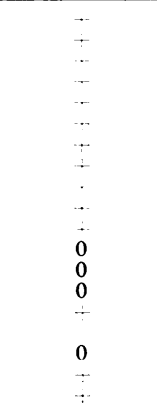 \\
\hline
\end{tabular}

* These patients developed gout.

In addition to these four patients, fifteen other cases of hyperparathyroidism (confirmed at operation) have been seen personally at Hammersmith Hospital and Taplow since 1947. They showed similar radiological lesions to those described above and in twelve out of the fifteen had clinical abnormalities in the joints. Most of these patients, however, had presented with pathological fractures or other gross signs of osteitis fibrosa and presented little diagnostic difficulty. Details of all nineteen cases are summarized in the Table, and further illustrations from Cases 5, 6, and 7 are shown in Figs 19 to 24 .

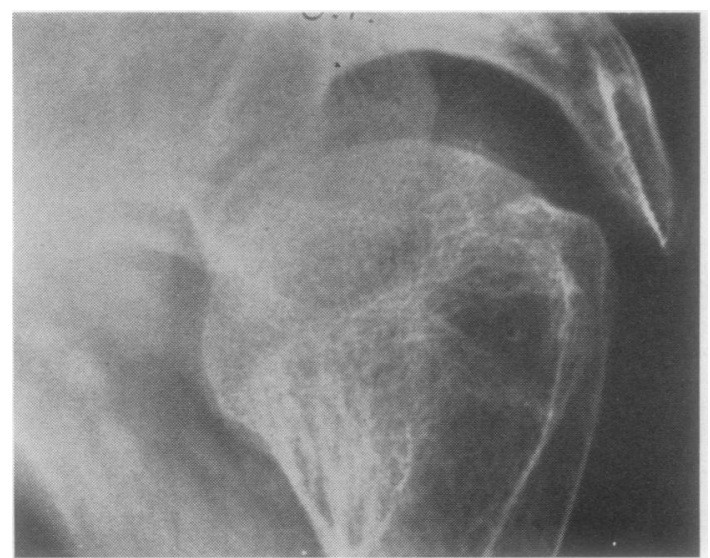

Fig. 19.-Case 5. Calcification of hyaline articular cartilage in shoulder. This was seen in most of the other joints as well as in the menisci in the wrist and in the proximal interphalangeal joint capsules
Of the nineteen cases, sixteen were women and only three men. Thirteen had raised blood urea (above $45 \mathrm{mg}$. per cent.) before operation, and

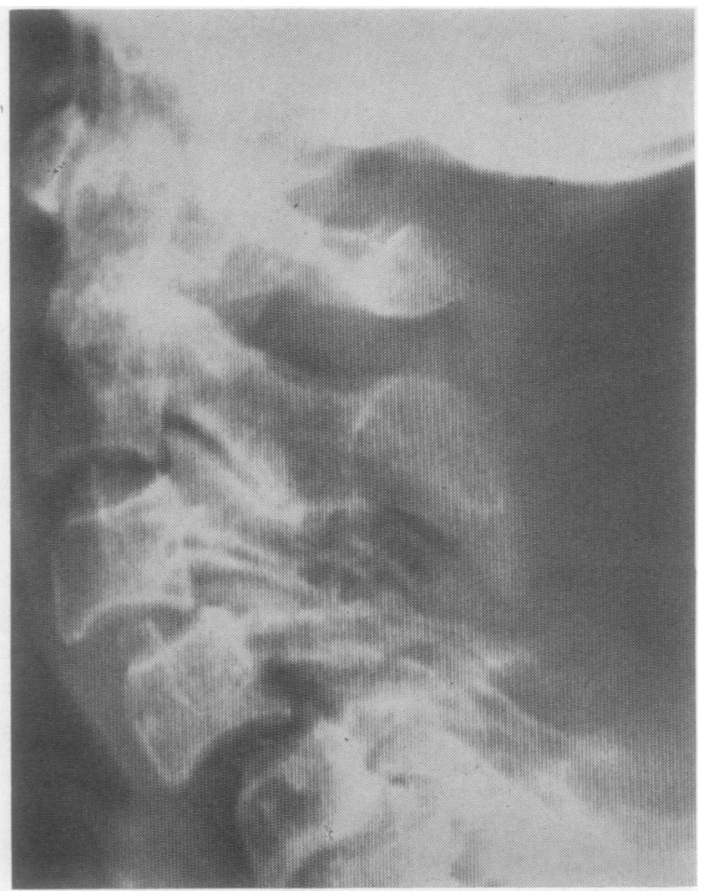

Fig. 20.-Case 5. Severe dislocation of cervical spine at C3-4 and C4-5, probably due to the softening of attachments of ligaments to bone. 

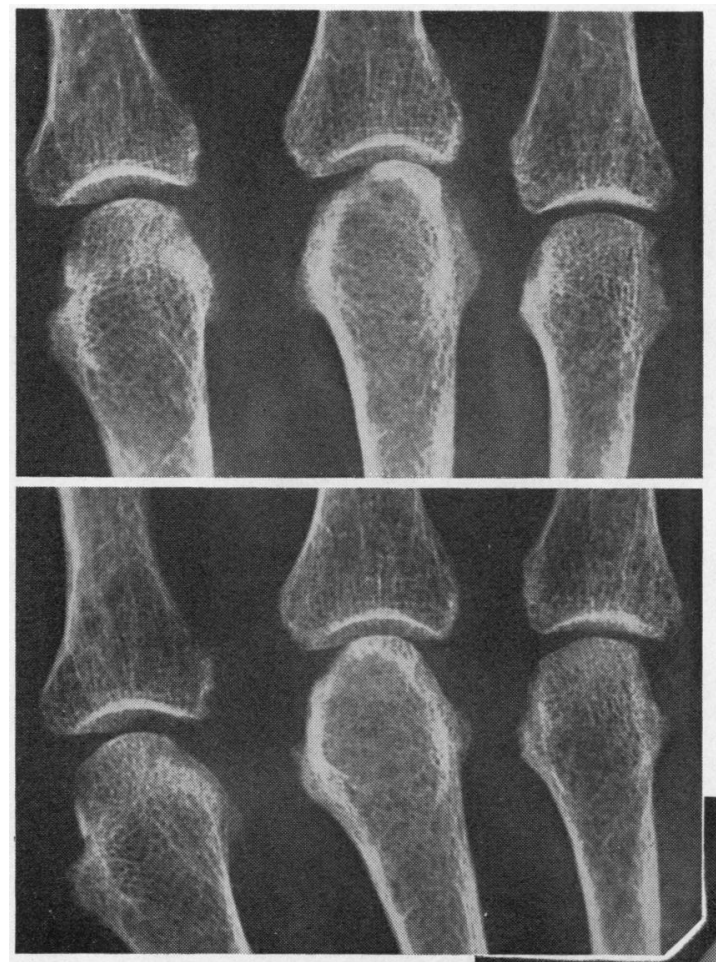

Fig. 22.-Case 7. Elbows, showing subchondral cystic erosions and cartilage loss at humero-ulnar articulation. The menisci of the knees and wrists were calcified in this patient with collapse of the external condyle of the right knee. (a)

Fig. 21.-Case 6. Metacarpophalangeal joints (a) immediately before and $(b) 1$ month after removal of parathyroid adenoma. The subchondral erosions are healing. There is some resemblance to the changes of rheumatoid arthritis.

(b)

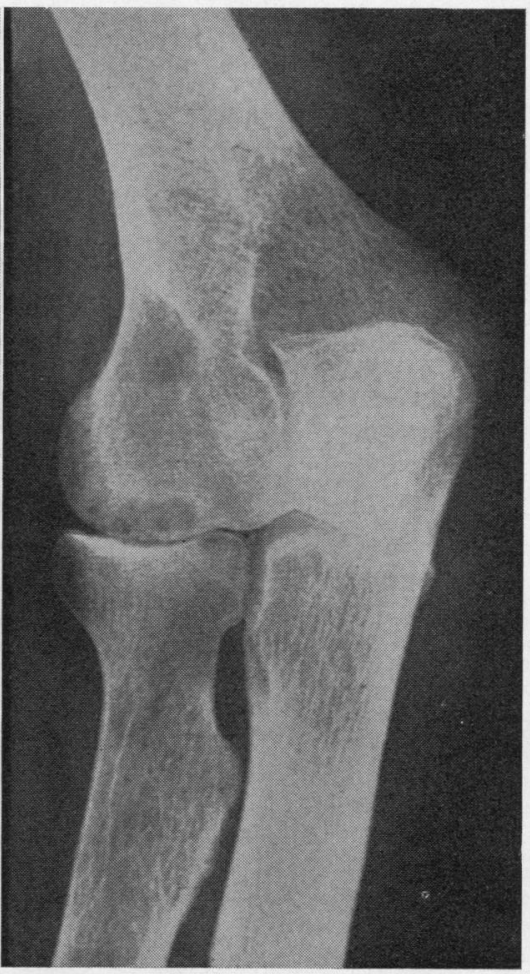

Left 


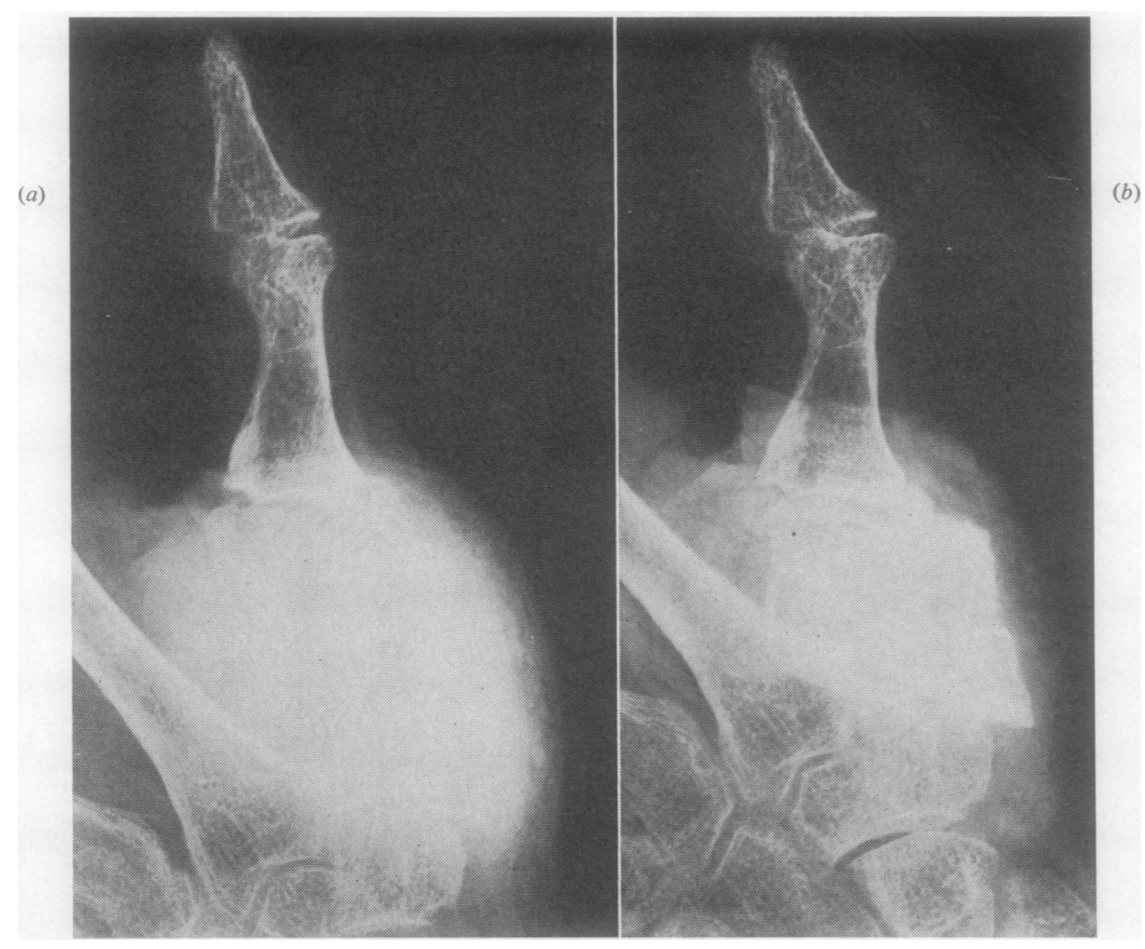

Fig. 23.-Case 6. (a) Complete collapse of first metacarpal 3 weeks pre-operatively; (b) Reconstituting itself 8 weeks after operation, but with joint irregularity.

sixteen had raised alkaline phosphatase (above 13 King-Armstrong units). The erythrocyte sedimentation rate (Westergren) was above $20 \mathrm{~mm}$./hr in five patients. Twelve patients complained of joint pain and eight had synovial effusions. Eleven showed soft tissue and cartilage calcification on $x$-ray examination and fourteen had bone erosions which were disclosed by radiology.

\section{Mechanism Involved}

The joint changes in these patients seem to be due primarily to a collapse of softened subchondral bone at sites of mechanical pressure. The changes in these metacarpal heads (Fig. 21) are reminiscent of those seen in Wilson's disease (Finby and Bearn, 1958) where there may also be osteomalacia, and of the subchondral erosions seen in hypercholesterolaemia (Ansell and Bywaters, 1957). In the latter condition and in Gaucher's syndrome, collapse of the femoral head with hip pain was thought to be due to weakening of the bone from cholesterol or kerasin infiltration. We have seen a similar phenomenon in a case of osteomalacia which presented as one of rheumatoid arthritis.

Case 20, a man aged 80, had a 6-year history of mild arthritis starting in the ankle (1953), and involving the left knee with a large effusion (1955), and the elbows and hand (1955). However, the erythrocyte sedimentation rate was $12 \mathrm{~mm} . / \mathrm{hr}$ and the Waaler-Rose test was negative. In 1956 other joints were the seat of complaint, and in 1957 the right hip became progressively more painful and disabling. There was progressive collapse of the femoral head (Fig. 25, overleaf) and of the medial condyle of the femur and tibia (Fig. 26, overleaf), leading to gross disability. An iliac crest bone biopsy showed moderately severe osteomalacia with osteoid seams of up to $45 \mu$ in width. This was ascribed to chronic renal impairment (Ca $5 \mathrm{mEq} / \mathrm{l}$; P $2 \mathrm{mEq} / \mathrm{l}$; alkaline phosphatase $15 \mathrm{King}$-Armstrong units; blood urea 60-65 mg. per cent.), because a jejunal biopsy (Dr. C. C. Booth) was within normal limits and no evidence of malabsorption was found. 


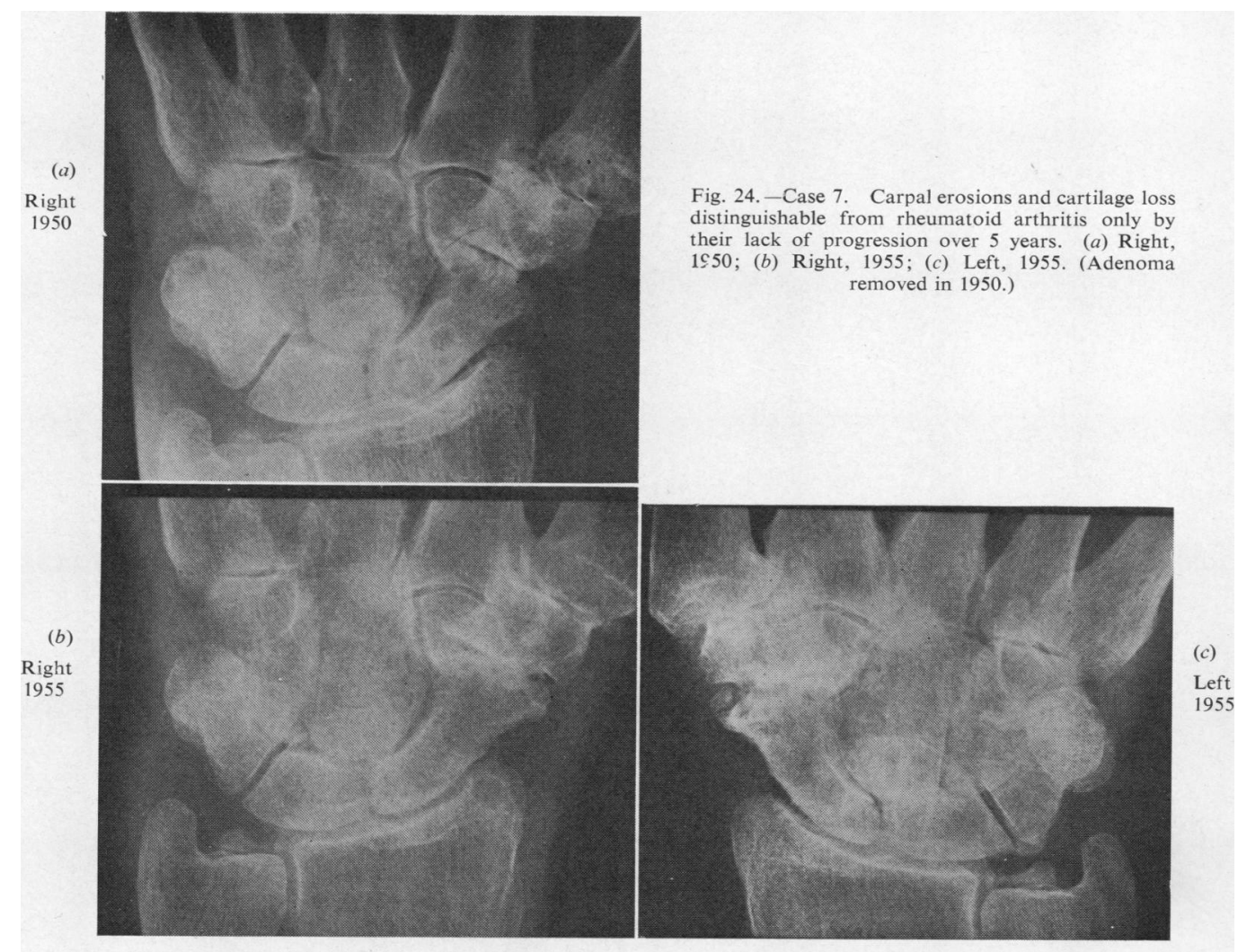

This patient was observed from 1953 to 1961 without any more adequate explanation of the osteomalacia.

The extent to which this patient's osteomalacia was the cause of his joint symptoms remains uncertain, but it is reasonable to suppose that it at least contributed to the collapse of the femoral head and knee joint. No other cause has been forthcoming. Using iliac crest bone biopsy as a screening procedure (Sacker and Nordin, 1954; Scott, Dixon, and Bywaters, 1959), a close watch has been kept for similar lesions in other cases of osteomalacia, and nine further patients with histologically proven osteomalacia have been seen. Four of these also had classical rheumatoid arthritis, the osteomalacia being due to previous gastrectomy, resistant rickets, and, in two cases, chronic nephritis: there seemed to be no additive effect of osteomalacia and rheumatoid arthritis. One patient had gout with renal disease and two had intestinal malabsorption without arthritis. The symptoms and radiological signs in these patients involved 


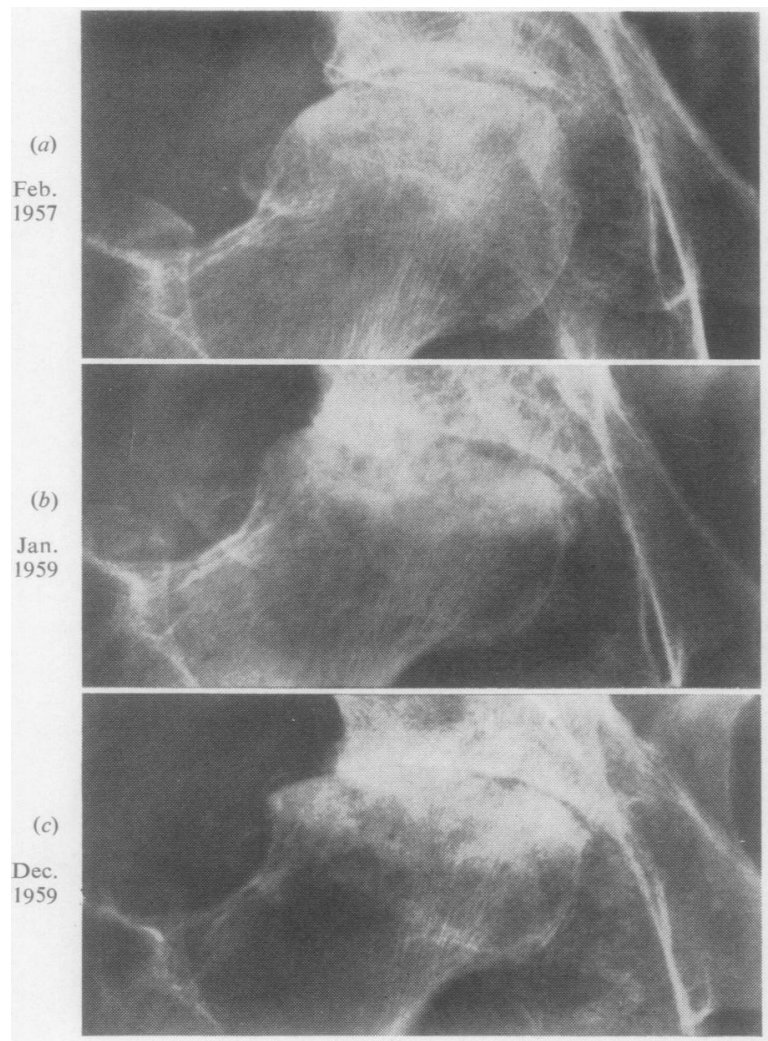

Fig. 25.-Case 20. Progressive collapse of right femoral head.

Fig. 26.-Case 20. Progressive collapse of medial femoral condyle with secondary osteo-arthrosis in left knee.

Chondrocalcinosis" by Žitňan, Sit'aj, and colleagues, 1963). It affects the surface and particularly the midzone of cartilage and the synovial lining of joints and tendon sheaths. It is only occasionally accompanied by overt metastatic calcification elsewhere, e.g. in blood vessels, but we believe it to be partly "metastatic" in origin, somewhat similar in fact to the gout that these patients sometimes show.* In the tendon and tendon sheath (Fig. 18) calcium deposits appeared on those areas subject to friction, e.g. the superficial surface of the flexor tendon sheath and tendon, and this suggests preferential localization in traumatized areas, i.e. it is possibly of a "dystrophic" character as well.

\footnotetext{
* A study of this is in preparation.
}

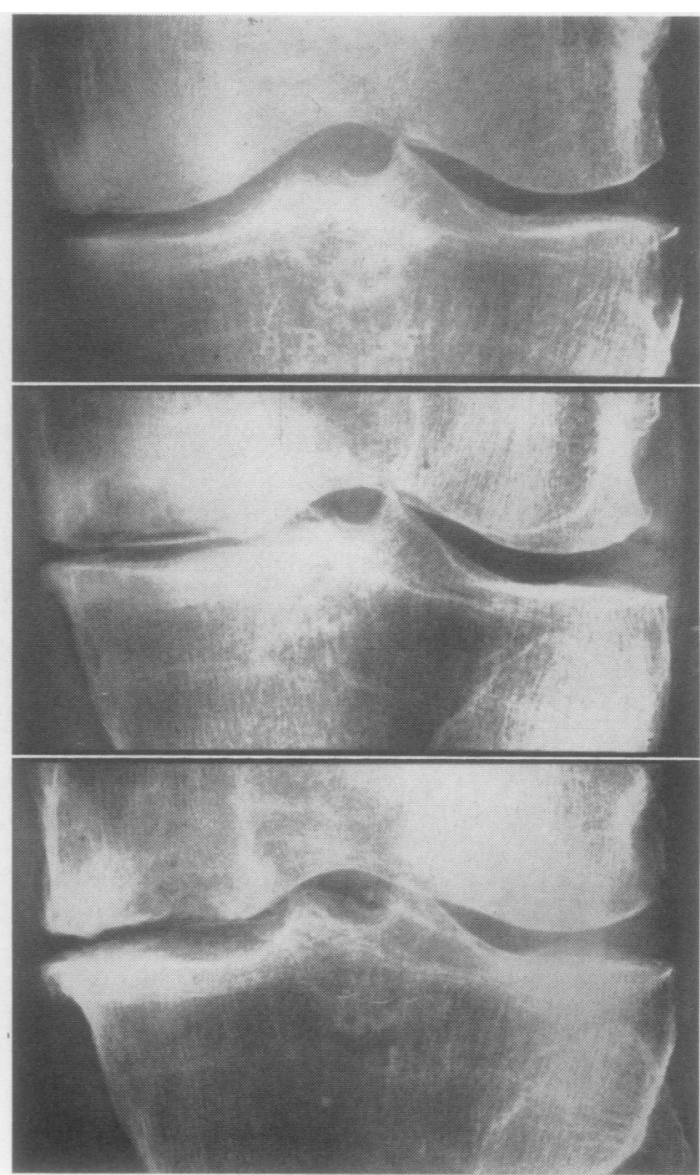

\section{Conclusion}

We conclude that patients with hyperparathyroidism and less commonly those with osteomalacia may suffer crush lesions of juxta-articular bone with a traumatic type of synovitis manifest by effusions and disability. Later osteo-arthrosis occurs. Some of these cases may mimic clinically and radiologically cases of rheumatoid arthritis. However, calcification in the synovial membrane and cartilage, common in these cases, is never seen in rheumatoid arthritis. It is important to recognize such presentations and to proceed to appropriate treatment.

Our thanks are due to our colleagues at Hammersmith and Taplow, particularly Prof. Russell Fraser, Dr. Gilliland, Dr. John Glyn, Mr. Arden, and Dr. John Lister for allowing us to see some of these patients. 
We are grateful to Dr. Oswald Savage and Dr. B. L. J. Treadwell for allowing us to cite the clinical details in Case 4.

\section{REFERENCES}

Ansell, B. M., and Bywaters, E. G. L. (1957). Ann. rheum. Dis., 16, 503.

Bywaters, E. G. L. (1959). Ibid., 18, 64 (Discussion).

Finby, N., and Bearn, A. G. (1958). Amer. J. Roentgenol., 79, 603.

Fraser, R., Harrison, M., and Ibbertson, K. (1960). Quart. J. Med., 29, 85.

Sacker, L. S., and Nordin, B. E. C. (1954). Lancet, 1, 347.

Scott, J. T., Dixon, A. S., and Bywaters, E. G. L. (1959). Ann. rheum. Dis., 18, 331.

Žitňan, D., Sit'aj, S., and colleagues (1963). Ann. rheum. Dis., 22, 142.

Zwaifler, N. J., Reefe, W. E., and Black, R. L. (1962). Arthr. and Rheum., 5, 237.

Lésions articulaires dans l'hyperparathyroïdisme

RÉSUMÉ

Des malades atteints d'hyperparathyroïdisme et, moins souvent, d'ostéomalacie peuvent souffrir de lésions d'écrasement de l'os juxta-articulaire avec une synovite du type traumatique se manifestant par l'épanchement et l'incapacité. Plus tard survient l'ostéoarthrose. Certains de ces cas peuvent simuler cliniquement et radiologiquement l'arthrite rhumatismale. Toutefois, la calcification de la membrane synoviale et du cartilage, commune dans ces cas, n'est jamais observée dans l'arthrite rhumatismale. Il est important de reconnaître ces manifestations pour appliquer un traitement approprié.

\section{Lesiones articulares en el hiperparatiroidismo}

\section{Sumario}

Enfermos con hiperparatiroidismo y, con menos frecuencia, los con osteomalacia, pueden padecer de lesiones aplastantes del hueso juxta-articular con una sinovitis del tipo traumático manifestándose por derrames e incapacidad. Luego ocurre una osteoartrosis. Algunos de estos casos pueden similar clínica y radiológicamente una artritis reumatoide. Sin embargo, la calcificación de la membrana sinovial y del cartílago, común en estos casos, nunca se ve en la artritis reumatoide. El reconocimiento de estas manifestaciones es importante para poder aplicar el tratamiento apropriado. 